\title{
XAMANISMO EM FOTOLIVROS DE CLAUDIA ANDUJAR: YANOMAMI E AMAZÔNIA
}

Shamanism in photobooks by Claudia Andujar: Yanomami and Amazônia

El chamanismo en fotolibros de Claudia Andujar: Yanomami y Amazônia

> Ana Carolina Albuquerque de Moraes [Universidade Estadual de Campinas, Brasil]*

RESUMO Este artigo propõe-se a analisar a abordagem do xamanismo yanomami pela fotógrafa Claudia Andujar em seus dois primeiros fotolivros, ambos de 1978: Yanomami: frente ao eterno (com Darcy Ribeiro) e Amazônia (com George Love). Em cada livro, são analisados o projeto gráfico, os assuntos dominantes e, sobretudo, o modo como o tema xamanismo é abordado. O viés das análises é sobretudo antropológico, coerentemente com o foco de Andujar na compreensão cultural dos Yanomami. Enquanto, em Yanomami, a abordagem do xamanismo é discreta, em Amazônia, é vigorosa pela quantidade de imagens dedicadas ao tema e a variedade de recursos visuais utilizados.

PALAVRAS-CHAVE Claudia Andujar; Xamanismo; Fotolivros; Yanomami; Amazônia.

* Ana Carolina Albuquerque de Moraes é professora do Departamento de Artes Visuais e Design da Universidade Federal de Sergipe e doutoranda em Artes Visuais na Universidade Estadual de Campinas. E-mail: carolina.moraes@gmail.com. Orcid: https://orcid. org/0000-0003-1560-2795 
DE MORAES, Ana Carolina Albuquerque. Xamanismo em fotolivros de Claudia Andujar: Yanomami e Amazônia. Revista Poiésis, Niterói, v. 23, n. 39, p. 224-252, jan./jun. 2022. [DOI: hitps://doi. org/10.22409/poiesis. v23i39.49154]

Este documento é distribuído nos termos da licença Creative Commons Atribuição -Não Comercial 4.0 Internacional (CC-BY-NC) (c) 2022 Ana Carolina Albuquerque de Moraes. Submetido: 12/3/2021 Aceito: 25/5/2021
ABSTRACT This article aims to analyze the approach on Yanomami shamanism by photographer Claudia Andujar in her first two photobooks, from 1978: Yanomami: frente ao eterno (with Darcy Ribeiro) and Amazônia (with George Love). The graphic design, the dominant subjects and, especially, the way in which the theme shamanism is addressed are analyzed in each book. The main bias employed in the analysis is anthropological, consistent with Andujar's focus on cultural understanding of the Yanomami. While in Yanomami the approach to shamanism is discreet, in Amazônia it is vigorous, due to the amount of images dedicated to the theme and the variety of visual resources employed.

KEYWORDS Claudia Andujar; Shamanism; Photobooks; Yanomami; Amazônia.

RESUMEN Este artículo se propone a analizar el enfoque del chamanismo yanomami por la fotógrafa Claudia Andujar en sus dos primeros fotolibros, ambos de 1978: Yanomami: frente ao eterno (con Darcy Ribeiro) y Amazônia (con George Love). En cada libro se analizará el proyecto gráfico, los asuntos dominantes y, sobre todo, la forma en que se aborda el tema del chamanismo. El sesgo de análisis es principalmente antropológico, consistente con el enfoque de Andujar en la comprensión cultural de los Yanomami. Mientras que, en Yanomami, el enfoque al chamanismo es discreto, en Amazonia es vigoroso, por la cantidad de imágenes dedicadas al tema y la variedad de recursos visuales utilizados. PALABRAS CLAVE Claudia Andujar; Chamanismo; Fotolibros; Yanomami; Amazônia. 
Claudia Andujar [1931-] aproximou-se do xamanismo e da cosmovisão yanomami aos poucos, à medida que construía uma relação de intimidade com as pessoas em suas sucessivas estadas na comunidade a partir dos anos 1970. Decidida a dedicar-se a um único povo por tempo indeterminado, foi-se inserindo entre os Yanomami e observando as relações interpessoais, as práticas cotidianas, a visão de mundo ali dominante. Desde o início, sentia a necessidade de entendê-los enquanto povo, mas, aos poucos, foi-se inteirando da complexidade da empreitada, pois compreender a visão de mundo de pessoas com origem e formação muito diferentes da sua, sem dominar a língua ali falada, não constituía tarefa fácil. A observação duradoura, participante, ao lado de outras estratégias que veio a conceber com o passar do tempo, como, por exemplo, a orientação para que algumas pessoas elaborassem desenhos representativos de sua própria realidade material e imaterial, foram recursos utilizados por Andujar para aproximar-se de um modo de vida tão marcado pela alteridade em relação a si mesma.

Alinhando-se a trabalhos anteriores [MORAES, 2018, 2019, 2020], este artigo propõe-se a analisar a abordagem do xamanismo yanomami pela artista em seus dois primeiros fotolivros: Yanomami: frente ao eterno, realizado em parceria com o antropólogo Darcy Ribeiro [ANDUJAR, 1978a], e Amazônia, este em parceria com o fotógrafo norte-americano George Love [ANDUJAR; LOVE, 1978]. As duas obras serão analisadas e comparadas quanto ao projeto gráfico, aos assuntos dominantes e, sobretudo, aos modos como o tema xamanismo é abordado em um e outro volume. Neste último ponto, as análises seguirão viés sobretudo antropológico, em consonância com o objetivo-mor de Andujar de compreensão cultural dos Yanomami.

A centralidade do tema xamanismo na obra da fotógrafa' pode ser vislumbrada em depoimentos seus, dentre os quais um que escreveu a respeito da série Sonhos Yanomami [1974-2003], cujas imagens constituem o foco da minha pesquisa de doutorado. ${ }^{2}$ Nessa série, concebida no início dos anos 2000, a artista sobrepõe fotografias de seu arquivo para refotografá-las sob novas projeções de luz, buscando evocar visões xamânicas. No depoimento em questão, afirmou a fotógrafa:

Considero a série 'Sonhos' um turning point em minha experiência com os Yanomami. As imagens que compõem a série revelam os rituais xamanísticos do Yanomami, 'sua reunião com os espíritos'. [...] Se o 
registro fotográfico de culturas pode ser considerado uma forma de compreensão do outro, eu acredito que com a série Sonhos eu consegui entender a essência do povo Yanomami [ANDUJAR, [2005].

Aquilo que Andujar considera "a essência do povo Yanomami" está, portanto, relacionado às visões acessadas pelos xamãs durante o transe - induzido pela inalação do psicoativo yãkoana ${ }^{3}$-, quando a cosmovisão yanomami revelar-se-ia do modo mais pungente, em virtude do contato dos xamãs com imagens ancestrais provenientes do passado absoluto. A série Sonhos é fruto da maturidade no relacionamento de Andujar com os Yanomami, após mais de trinta anos de convivência. Antes dela, a artista já havia abordado o tema xamanismo em outros trabalhos, como nas séries O invisível[1974-76] e Reahu[1974-76], e em sequências imagéticas em fotolivros, como Yanomami: frente ao eterno e Amazônia, focos deste artigo. Cada livro aborda o tema a seu modo, com maior ou menor ênfase, no âmbito de diferentes estratégias discursivas, conforme será aqui discutido.

Ambos os volumes foram publicados em 1978, pela Editora Praxis. Até então, Andujar havia estado entre os Yanomami em cinco momentos distintos: em 1971, enquanto fotografava para uma edição especial da revista Realidade sobre a região amazônica, estabelecendo seu primeiro contato com a comunidade; em dezembro do mesmo ano, durante três dias, na companhia de Love, então seu marido; em 1972, por cerca de um mês, acompanhando atividades cotidianas, como caça, pesca e coleta de mantimentos; em 1974, quando ali permaneceu a maior parte do ano, participando de modo imersivo das atividades coletivas e fotografando largamente as cerimônias funerárias denominadas reahu; entre 1976 e 1977, durante quatorze meses, quando desenvolveu projeto de pesquisa financiado pela FAPESP [Fundação de Amparo à Pesquisa do Estado de São Paulo], em que buscava estimular alguns Yanomami a desenharem e narrarem aspectos de sua própria cosmovisão, como forma de apreendê-la em maior profundidade [NOGUEIRA, 2018, p. 167-203].

Nas duas últimas estadas mencionadas, a fotógrafa estreitou os laços com o xamanismo yanomami. Em 1974, fotografando as cerimônias reahu, presenciou, por diversas vezes, a inalação coletiva de yãkoana pelos participantes do sexo masculino no último dia do evento. As festas reahu, que se estendem por vários dias e acolhem convidados de diferentes aldeias, são cerimônias funerárias em que os participantes lamentam os mortos e ingerem suas cinzas misturadas em mingaus, de modo a garantir a ascensão de seus espíritos 
para as "costas do céu" [KOPENAWA; ALBERT, 2015]. No derradeiro dia de festa, todos os homens inalam yãkoana e praticam xamanismo, buscando alcançar um outro patamar de consciência em que seria possível o contato com espíritos florestais. ${ }^{4}$

A relação de Andujar com aqueles identificados na aldeia como "xamãs" foi aprofundada enquanto a fotógrafa desenvolvia a pesquisa fomentada pela FAPESP, em 1976-77. Suas imersões anteriores em território yanomami despertaram-Ihe o interesse em conhecer mais detidamente aspectos da cosmovisão do grupo. A dificuldade de comunicarse oralmente com seus interlocutores foi um dos fatores que a impulsionaram a solicitar-Ihes a materialização em desenhos de aspectos dessa cosmovisão. Os conteúdos dos desenhos eram verbalizados por seus autores, e o material gravado em Yanomami era posteriormente traduzido para o português por Carlo Zacquini, missionário italiano que se tornou fiel parceiro da fotógrafa na luta pela causa ameríndia [ANDUJAR, 1978b]. Segundo Andujar, no interior do grupo, "os que mais se interessaram em desenhar foram os xamãs" [ANDUJAR, 2005, p. 109] - o que talvez decorresse do fato de serem eles os membros da aldeia mais acostumados a lidar com "imagens", embora de outra natureza, nos sonhos induzidos pela yãkoana.
A pesquisa foi bruscamente interrompida em 1977, com a expulsão da fotógrafa das terras yanomami pelo governo militar, que a enquadrou na Lei de Segurança Nacional, provavelmente por suspeitas de que suas imagens seriam utilizadas contra o regime. De volta a São Paulo, e revoltada com a expulsão da Amazônia, Andujar lançou-se firmemente na militância política, fundando, juntamente com Carlo Zacquini e o etnólogo francês Bruce Albert, a Comissão pela Criação do Parque Yanomami [CCPY], organização não-governamental que coordenou por mais de vinte anos. Também se dedicou à organização de seu amplo arquivo fotográfico yanomami, selecionando parte desse material para publicação. Yanomami: frente ao eterno e Amazôniavieram à luz nesse período.

Ambos os livros foram censurados pelo governo militar e, mesmo após o fim do regime, nunca chegaram a ser disponibilizados em livrarias, apenas em sebos. Segundo Andujar, transtornado com as duas censuras, José Regastein Rocha, diretor da Praxis, abandonou a empresa e, em seguida, a própria editora chegou ao fim [ANDUJAR, 2010, n.p.]. A raridade dos livros, sua qualidade artística e relevância na trajetória de Andujar fazem com que, atualmente, exemplares cheguem a atingir preços robustos em sebos virtuais. 
Yanomami: frente ao eterno foi o primeiro dos três livros ${ }^{5}$ lançados por Claudia Andujar em 1978. O volume, realizado em parceria com Darcy Ribeiro, inaugurava a série intitulada Memória Social da Editora Praxis, dedicada a tratar de "temas sociais brasileiros", segundo a editora [ANDUJAR, 1978 a, n.p.]. Nele, há a apresentação de Claudio e Orlando Villas Boas, além de textos de Andujar e Ribeiro, todos tocando, em maior ou menor grau, nas a meaças físicas e simbólicas a que estavam submetidos os Yanomami pelo recente contato com a sociedade dita civilizada. O livro é dedicado à memória do pai da fotógrafa - morto em campo de concentração nazista, assim como toda a sua família paterna, de origem judia -, e a experiência traumática da guerra surge pontualmente, em texto de sua autoria, relacionada ao desterro dos Yanomami: "[...] essa procura partiu de mim, de meu próprio sofrimento e vida, mas me ultrapassou e abarcou o destino de um povo, como o dos Yanomami, com o qual me identifiquei e cuja luta virou minha luta" [ANDUJAR, 1978 a, n.p.].

O projeto gráfico foi pensado pelo artista Wesley Duke Lee, com margens amplas e abundância de fundo branco [NOGUEIRA, 2018, p. 203]. Ao longo das páginas, trechos curtos sobre o cotidiano e a cosmovisão yanomami ocupam pequeno espaço em canto inferior de página majoritariamente branca, acompanhando e contextualizando uma imagem que geralmente se encontra na página ao lado. Cada fotografia situa-se no interior de um retângulo de linhas pretas muito finas, que Ihe serve de moldura e a faz flutuar no espaço. cria-se o ambiente propício para que o olhar se demore sobre as imagens em si, com rápidas digressões para as frases adjacentes [Fig.1].

As fotografias, todas em preto-e-branco, mostram partes de corpos yanomami: rostos [frente e perfil], seios, nuca, barriga grávida, dorso, torso, mãos, vagina, etc. Em meio aos fragmentos de corpos, alguns artefatos culturais são enfatizados: colares de miçangas, brincos de penas, braçadeiras, tangas femininas, cordões penianos, dentre outros. Ora as figuras aparecem sozinhas, ora em pares. As imagens são feitas a uma distância muito pequena dos retratados, fruto da intimidade que a artista havia desenvolvido com eles ao longo dos anos de convivência: às vezes, parece que podemos tocar um rosto, uma mão, uma barriga, uma nuca. Claudia nos deixa a sós com a intimidade de seus modelos em meio à imensidão branca da página. 


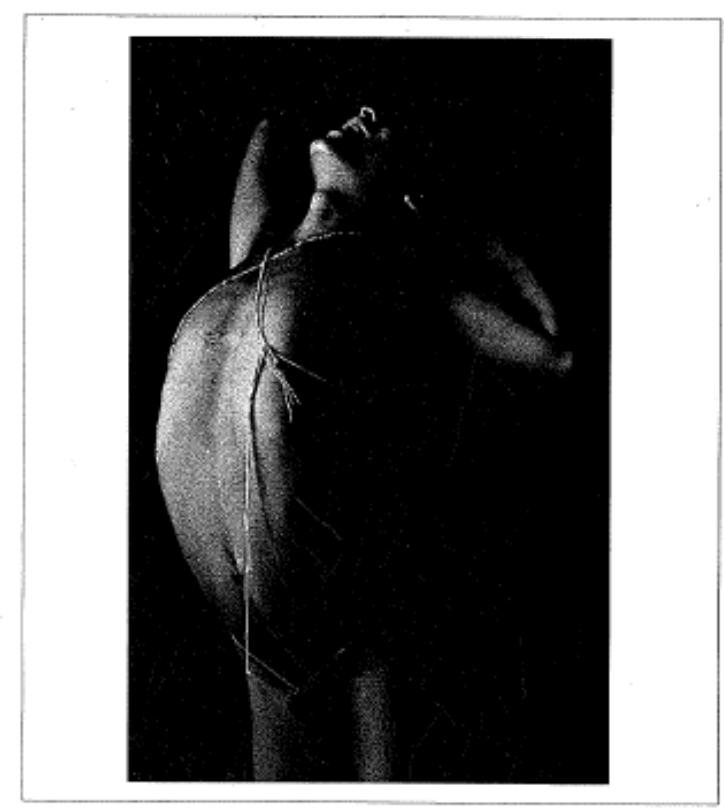

Fig. 1 - Página dupla de YANOMAMI: FRENTE AO ETERNO.

[Fonte: ANDUJAR, Claudia. YANOMAMI: FRENTE AO ETERNO. São Paulo: Práxis, 1978a.]

Segundo Thyago Nogueira [2018], as fotografias foram realizadas entre 1974 e 1976, fazendo uso apenas da iluminação natural no interior das malocas. Percebe-se, no entanto, que uma imagem foge a essa regra, denunciando o uso de flash, como veremos adiante. Nogueira ressalta que quase um filme inteiro era consumido em cada retrato, a fim de que fotógrafa e modelo pudessem aprofundar a intimidade ao longo dos cliques.
Em meio às trinta e oito fotografias do livro, apenas três aludem ao xamanismo. Elas se situam ao final do volume, como que à espera de que o espectador/ leitor adquirisse maior familiaridade com os Yanomami e seus artefatos antes de ser introduzido a um tema de maior complexidade. Na primeira das três imagens, um homem cobre a parte inferior do rosto com uma das mãos [Fig.2]. Os caminhos tremulantes de luz que o ladeiam sugerem que ele inala 
o psicoativo yãkoana e entra em contato com os xapirí [entidades que, para os Yanomami, são algo como espíritos da floresta], cuja presença na imagem justificaria os intensos contrastes claro-escuro em livro dominado pelas baixas luzes. Trata-se da única imagem do volume que atesta a presença de flash em sua construção. Em várias passagens do livro A queda do céu[2015], o xamã yanomami Davi
Kopenawa e o etnólogo Bruce Albert referem-se à visão da chegada dos xapiri como a aproximação de frenéticos caminhos de luz, que viriam ao encontro do xamã durante o transe. À medida que Andujar compreendia mais profundamente o universo xamânico, por meio de longas estadas na comunidade e do contato próximo com xamãs, passava a criar estratagemas técnicos que fizessem alusão a

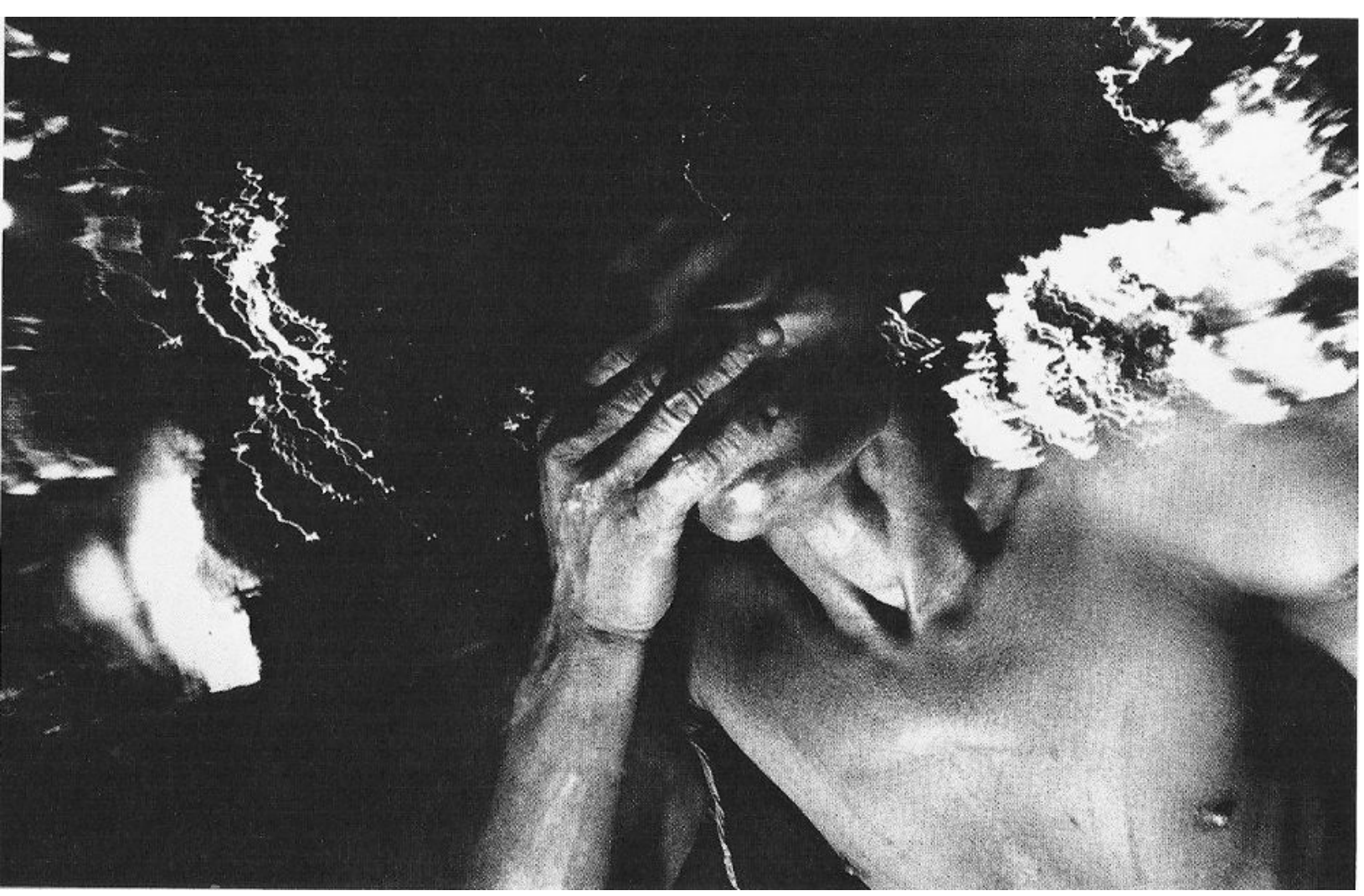

Fig. 2 - Claudia Andujar, Sem Título, 1974-1976. Fotografia.

[Fonte: ANDUJAR, Claudia. Yanomami: frente ao eterno. São Paulo: Práxis, 1978a] esse modo de conhecimento. A combinação de flash, longa exposição e movimento da câmera torna-se recurso largamente utilizado pela fotógrafa em imagens que abordam o xamanismo yanomami, evocando a presença e o deslocamento dos xapiri.

DE MORAES, Ana Carolina Albuquerque. Xamanismo em fotolivros de Claudia Andujar: Yanomami e Amazônia. 


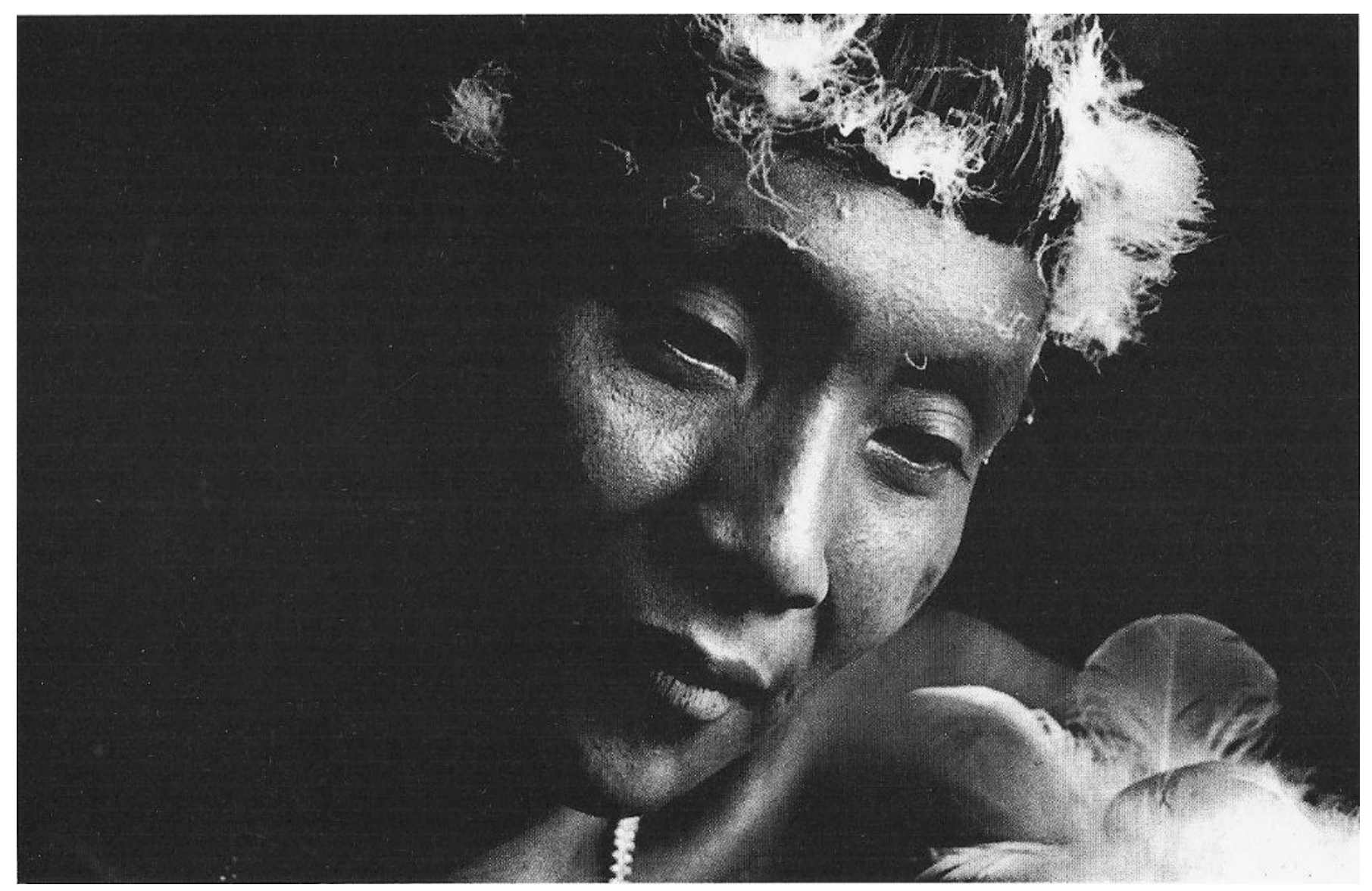

Fig. 3 - Claudia Andujar, Sem Título, 1974-1976. Fotografia.

[Fonte: ANDUJAR, Claudia. Yanomami: frente ao eterno. São Paulo: Práxis, 1978a]

Na fotografia seguinte, um rosto masculino, sutilmente emergido da escuridão, fita carinhosamente um adorno com plumas, provavelmente uma braçadeira, enquanto sua cabeça está enfeitada com penugens brancas [Fig.3]. O texto relacionado a essa imagem diz: "O adorno é mais que um enfeite, é uma identificação com o mundo espiritual" [ANDUJAR, 1978a, n.p.]. Os Yanomami enfeitam-se para receber os xapiri durante as festas reahu. Cada enfeite teria um respectivo correspondente no mundo invisível.

Revista Poiésis, Niterói, v. 23, n. 39, p. 224-252, jan./jun. 2022. [DOl: https://doi.org/10.22409/poiesis.v23i39.49154] 


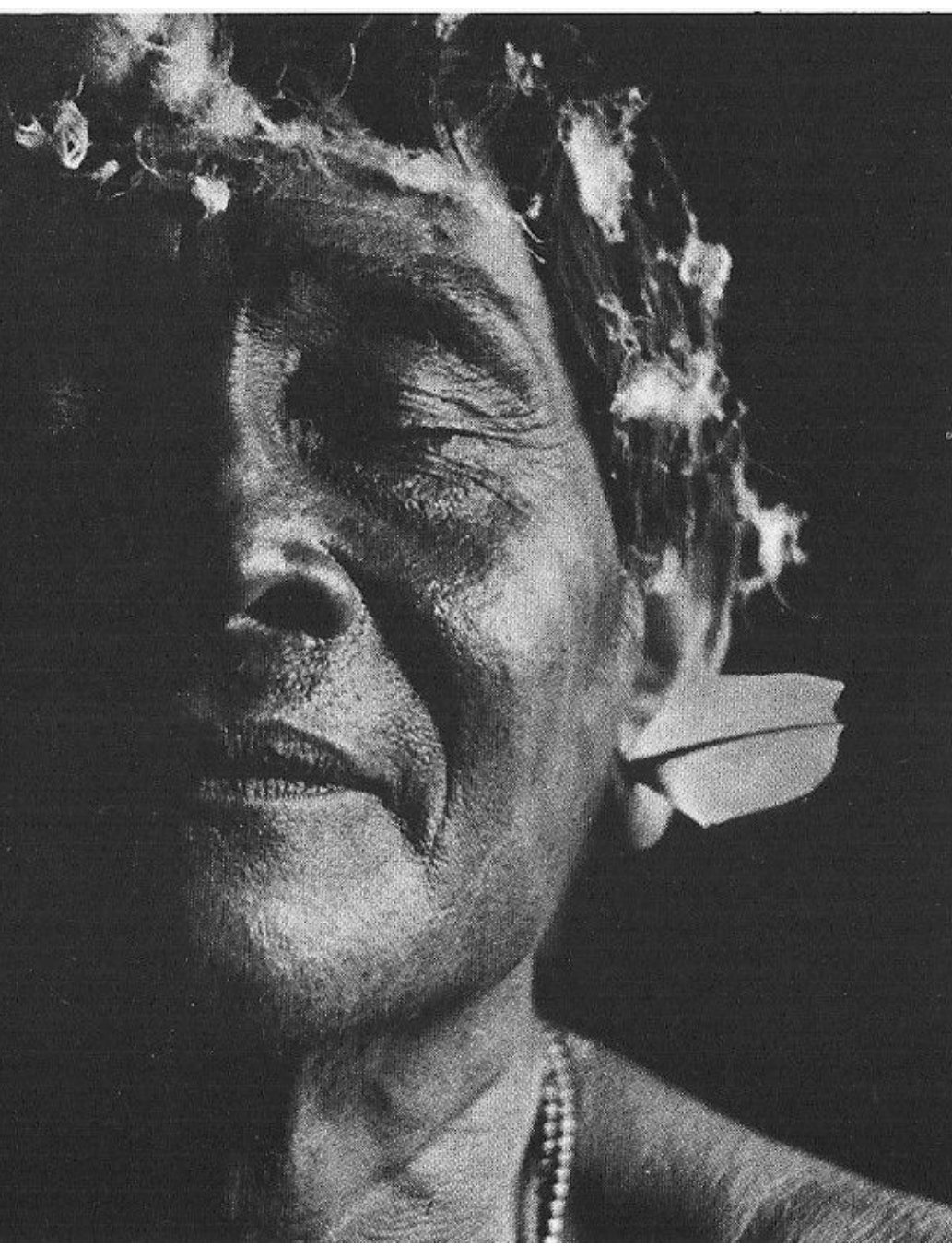

Fig. 4 - Claudia Andujar, Sem Título, 1974-1976. Fotografia.

[Fonte: ANDUJAR, Claudia. Yanomami: frente ao eterno. São Paulo: Práxis, 1978a] 
Descrevendo detalhadamente os xapiri, Kopenawa e Albert enfatizam todo o seu esmero com a aparência antes de virem ao encontro dos xamãs: pintam os corpos e enchem-se de adornos para causar deslumbre. "Tem um porte muito imponente! Foi Omama que os ensinou a se enfeitar assim. Quis que fossem magníficos para vir nos mostrar sua dança de apresentação", comentam os autores, referindo-se ao demiurgo yanomami [KOPENAWA; ALBERT, 2015, p. 112]. Nos braços, os xapiri levam "muitos penachos de penas de papagaio e caudais de arara fincadas em braçadeiras de belas miçangas lisas e coloridas, com muitas e muitas caudas de tucano e despojos multicolores de pássaros wisawisama sipendurados" [KOPENAWA; ALBERT, 2015, p. 112]. Bastante exigentes, os xapiri demandam que seus anfitriões terrenos estejam adornados à altura para recebê-los; caso contrário, podem desistir da visita. Na imagem, o olhar atento da figura para o adorno parece evocar seu apreço pelos significados do objeto.

A penúltima imagem do livro mostra a metade esquerda do rosto de um homem maduro, a outra metade diluindo-se na escuridão [Fig.4]. Com os olhos fechados e o semblante sereno, usa brinco de pena e penugens brancas sobre a cabeça. Os adornos e a expressão tranquila, os olhos fechados sugerindo sono profundo, fazem-nos pensar em um xamã experiente em contato com os xapiridurante seus sonhos.

Apenas a fotografia seguinte, última do livro, faz referência ao contato com os brancos, como que a lembrar, após o êxtase xamânico, que aquela organização social se encontrava ameaçada pela chegada de invasores e seus signos. Um Yanomami é retratado do peito para cima com camiseta listrada e mão sobre o queixo, em pose comum a modelos ocidentais masculinos. Ao lado da imagem, o pequeno trecho textual constata a mudança e sutilmente a lamenta: "Um novo mundo abriu-se aos seus olhos. Ele é um ESTRADATHERI, morador da estrada" [ANDUJAR, 1978a, n.p.; grifo no original], em referência à construção da rodovia Perimetral Norte, que atraiu alguns grupos Yanomami para a vida às margens da estrada, mesmo após o abandono das obras, em 1976 [NOGUEIRA, 2018]. Em texto na sobrecapa do volume, Andujar explicita sua preocupação: "Nos limites da ética tribal, há uma margem grande de tolerância para o não convencional e eles se adaptam com facilidade ao novo; por isso, são vulneráveis a uma desaculturação7 rápida que pode se tornar extremamente perigosa" [ANDUJAR, 1978a, n.p.].

Em consonância com o tom de denúncia dos textos, há, nas últimas páginas, um desenho e um texto atribuído ao xamã Wárasi Hwayautheri, com 
quem Andujar desenvolveu forte amizade [ANDUJAR, 2005, p. 119]. No texto, intitulado Os espíritos do xamã abandonado, Wárasi lamenta a perda de confiança em si mesmo e seus poderes, já que não teria conseguido livrar seus parentes da morte [em virtude das epidemias contraídas dos trabalhadores da estrada]. Atribui sua incapacidade à partida da maior parte de seus espíritos auxiliares [xapiri], que teriam retornado às suas casas, no topo das montanhas. O texto termina com a declaração cética e dolorosa: "Não sou mais xamã" [HWAYAUTHERI, In: ANDUJAR, 1978a, n.p.].

Apesar desse texto, o xamanismo é abordado com discrição em Yanomami: frente ao eterno. Andujar introduz sutilmente o espectador/leitor ao tema, em poucas imagens. Não é tema forte no livro, que imageticamente se foca nos retratos e fragmentos de corpos e artefatos, enquanto textualmente prioriza a denúncia das consequências nocivas do contato entre os Yanomami e a sociedade externa.

\section{AMAZÔNIA}

Se Yanomamié sóbrio, quanto às imagens e à diagramação, folhear Amazônia [ANDUJAR; LOVE, 1978] é uma experiência de abundância em vários aspectos: de paisagens, de efeitos fotográficos, de quantidade e tamanho das imagens reproduzidas. O projeto gráfico é do mesmo Wesley Duke Lee, que dessa vez, dado o tema e a natureza das imagens, enveredou por caminhos diversos: margens externas, superiores e inferiores estreitas, emoldurando as fotografias, e ausência de margens internas, resultando em pouco espaço em branco na quase totalidade das páginas.

O livro não apresenta texto, apenas fotografias em cores de Andujar e Love. Em projeto anterior, de 1973, o volume deveria conter quarenta páginas de texto, além de cento e quarenta e quatro de fotografias. Essa versão não teria vingado em virtude do alto custo do exemplar e de divergências entre autores e editor. O livro foi publicado, em diferente configuração, em 1978, também pela Praxis. A editora havia planejado a inclusão de um único texto no volume, encomendado por Regastein Rocha ao poeta amazonense Thiago de Mello, que acabava de retornar ao Brasil após exílio político [ANDUJAR, 2010]. Pelo teor das críticas ambientais do poeta, no entanto, o texto não passou pela censura dos militares, e o livro acabou por ser publicado apenas com imagens [NOGUEIRA, 2018, p. 206].

Segundo Thyago Nogueira [2018], Love foi o principal idealizador do volume. Queria ele que, por meio das imagens, a publicação abordasse, com igual nível de importância, o tema "Amazônia" e o meio fotográfico: a região amazônica sendo mostrada em fotografias que eram, em si, construções 
da realidade. A ideia da fotografia como artifício - construção em vez de "espelho" - é fortemente ressaltada no livro. Embora as imagens descortinem as dimensões gigantescas e certas particularidades paisagísticas e humanas da Amazônia, os autores não nos deixam imergir simplesmente no assunto. Somos constantemente lembrados de que estamos diante de imagens, com elevado grau de pensamento construtivo. Assim, as pontas de negativos fotográficos reproduzidas na abertura e no fechamento da sequência imagética - e que ressurgem em páginas intermediárias - lembram-nos continuamente de que, entre nós espectadores e as realidades mostradas nas imagens encontra-se, invariavelmente, o filme fotográfico. O mesmo ocorre quando nos deparamos com margens de fotogramas impressas nas páginas. Talvez pelo mesmo motivo, as imagens, embora reproduzidas quase do tamanho do formato da página, não "sangrem", não alcançando as bordas do papel. Emoldurando as fotografias, há margens que, embora estreitas, não nos deixam esquecer de que estamos diante de recortes, artificialmente construídos, da realidade.

Um depoimento de Love é particularmente elucidativo a esse respeito:

Na verdade, o livro surgiu das convicções sobre a natureza da fotografia e sobre a experiência na região, numa tentativa de conciliar ideias desses dois universos.
A Amazônia era o tema, mas o objetivo era mostrar que uma foto não é uma representação fiel do assunto. $\bigcirc$ livro foi construído para traduzir esta tese, de que aquilo que a fotografia mostra é uma impressão da realidade, apenas a minha impressão. $\bigcirc$ que você vê é a foto da floresta, não a própria. Não é o céu que você vê, é o filme. Não é um livro da Amazônia, é um livro de filmes. O livro nunca foi entendido. Também, ele foi simplesmente banido, na época áurea da censura. Nunca chegou ao público. Tiraram o texto. Achávamos suficiente o leitor ter uma introdução poética da recriação de atmosfera para estar preparado a se lançar nas imagens, onde a atmosfera, e não a fidelidade a um assunto, era o objetivo [LOVE, apud NOGUEIRA, 2018, p. 205].

Quanto à materialidade da imagem e aos jogos visuais envolvidos, Amazônia faz uso abundante de texturas, repetições, espelhamentos e sequências. Há fartura de texturas diversas, em motivos que muitas vezes não se deixam reconhecer, mas que certamente nos introduzem a certa "atmosfera" amazônica, como Love queria. Por essa valorização da materialidade dos elementos, Amazônia torna-se um livro intensamente tátil, embora por recursos puramente bidimensionais. O uso de repetições é também frequente. Muitas fotografias são reproduzidas mais de uma vez, ou de maneira idêntica ou, como é mais frequente, com tratamentos diferenciados - espelhamentos, rotações, novos enquadramentos e intervenções de luz, etc. -, de modo a nos lembrar, uma 
vez mais, sobre a materialidade e o caráter de invenção da imagem fotográfica.

As imagens não são individualmente assinadas, embora saibamos que as fotografias aéreas são atribuídas a Love - que, por ser asmático, não podia ficar longos períodos na umidade da floresta -, e que as fotos de Yanomami foram realizadas por Andujar. Aproximadamente até a metade, o livro é dominado por fotografias aéreas, que exploram variadas texturas - de nuvens, água, rochas, solos, copas de árvores - e nos dão ideia da magnitude da região. Uma ponta de filme marca o intervalo e nos direciona a uma escala terrena, na qual novamente nos deparamos com águas e plantas, porém a partir de um ponto de vista mais horizontal. Da escala macro das paisagens vistas de cima, passamos à escala micro de texturas de folhas, por exemplo. É nesse momento que somos introduzidos às fotografias de Yanomami.

Eles surgem sorrindo, brincando e descansando em redes, descontraídos em sua vida cotidiana. Em páginas duplas, Claudia explora sequências, como duas fotografias de uma mesma pessoa ou dupla em momentos subsequentes, para transmitir a ideia do fluxo contínuo do tempo na vida tranquila de Yanomami isolados. Há também paralelismos, como, numa página dupla, duas fotografias de pessoas em redes - uma moça à esquerda, um garoto à direita -, sem necessariamente nenhuma relação anterior à justaposição das imagens. Há ainda muitas pausas, que ajudam a dirigir o olhar para a imagem da página ao lado. Na imensidão de uma página dupla, por exemplo, olhamos especificamente para a pequena folha amarela mostrada por uma moça que brinca de esconder-se atrás dela.

Novamente, como última sequência do livro, deparamo-nos com imagens de reahue xamanismo. São dezesseis páginas duplas, de um total de setenta e seis com imagens no volume. Mais uma vez, a margem impressa de um fotograma indica a pausa e a passagem para o novo tema. Diferentemente do restante do livro, predomina nessa sequência a exposição de uma imagem figurativa por página dupla, a outra página contendo foto não figurativa, apenas com manchas de luz, exibindo às vezes a margem do fotograma. São dez páginas duplas com essa configuração, contra seis mostrando uma imagem figurativa em cada página simples. Provavelmente pelo caráter, em certa medida, secreto desses rituais, e pela profunda entrega emocional das pessoas que deles participam, os autores optaram por mostrar aos poucos as imagens que os abordam, intercaladas por longas pausas que, em alguns momentos, parecem solicitar do espectador o silêncio e a reverência, e, em outros, parecem evocar sensações e visões xamânicas durante o transe. 
A sequência começa com o rosto de um garoto de olhos fechados e segue para uma imagem em que três pessoas agachadas, provavelmente um xamã em primeiro plano, têm posturas e expressões que acusam o uso recente da yãkoana. Na próxima página dupla, à direita, dois homens abraçados parecem cantar e dançar, um deles com penugens brancas sobre a cabeça [Fig.5, em cima]. Ao redor do par, vemos timidamente os ondulantes caminhos de luz que Andujar usa para evocar a chegada dos xapiri, baseada em relatos dos próprios Yanomami sobre a configuração desse evento em suas visões xamânicas. Enquanto isso, a página à esquerda mostra listras verticais em diferentes tonalidades de amarelo, uma delas misturando-se ao vermelho. Os amarelos contrastam veementemente com o fundo negro e as baixas luzes predominantes na imagem à direita.

Relatando o processo de iniciação xamânica do primeiro, Kopenawa e Albert [2015] contam que, após a inalação da yãkoana, a imagem do corpo do xamã foi levada pelos xapiripor alturas e profundidades longínquas, voando muito acima das montanhas e abaixo da superfície da terra. Num dado momento, sua visão de sonho foi dominada por uma claridade ofuscante: uma luz intensa espalhou-se por toda parte, não mais the deixando reconhecer qualquer motivo. Tal experiência luminosa foi-Ihe decisiva para compreender que, naquele momento, tornava-se outro, assumia a perspectiva de outrem - a dos xapiri -, conforme será discutido mais adiante.

Viveiros de Castro [2006] lembra que, entre os povos ameríndios da Amazônia, é frequente a associação da percepção luminosa intensa demais à aproximação dos espíritos. Ponderando que tal visão de claridade absoluta pode estar associada à ingestão de psicoativos, como a yãkoana, surgindo como efeito bioquímico, afirma que tal explicação, obviamente, não é válida nas cosmovisões ameríndias, para as quais tais substâncias são canais que permitem a conexão com o mundo invisível, por onde os xamãs transitam a fim de descobrir a ampla rede de intencionalidades subjacente ao mundo visível. De modo poético, o autor relaciona a invisibilidade dos espíritos para as pessoas comuns à sua altíssima frequência luminosa, que estaria situada acima do espectro visível: um "caráter super-visível" distinguiria esses seres [VIVEIROS DE CASTRO, 2006, p. 332]. Na imagem em questão, é possivel pensar que os homens abraçados, empoderados pela yãkoana, tenham acesso, em seus sonhos, à claridade ofuscante dos xapiri.

O ápice desse raciocínio parece surgir na página dupla seguinte, uma das mais impressionantes [Fig.5, embaixo]. Na página à esquerda, as linhas 
de luz branca assumem tamanhas densidade e espessura que chegam a tornar-se verdadeiras massas de luz, riscos concentrados meio amorfos cuja gestualidade orgânica talvez lembre uma action pain-

ting, agora inscrita com luz. Os riscos invadem e cortam a composição com voracidade tal que, da pessoa retratada, distinguimos apenas os olhos, perdidos em meio à potência da luz branca. A página à direita é de um branco ofuscante quase total, maculado apenas por uma oscilante linha preta amarelada que o corta verticalmente. Os xapiri andujarianos parecem assumir aqui, quase, o tal "caráter super-visível".

Fig. 5 - Páginas duplas de Amazônia.
Em algumas páginas duplas, uma das metades é ocupada por fotografia em que não se reconhece motivo algum, apenas luzes difusas como que remetendo a visões durante intensa vertigem [Fig. 6] .
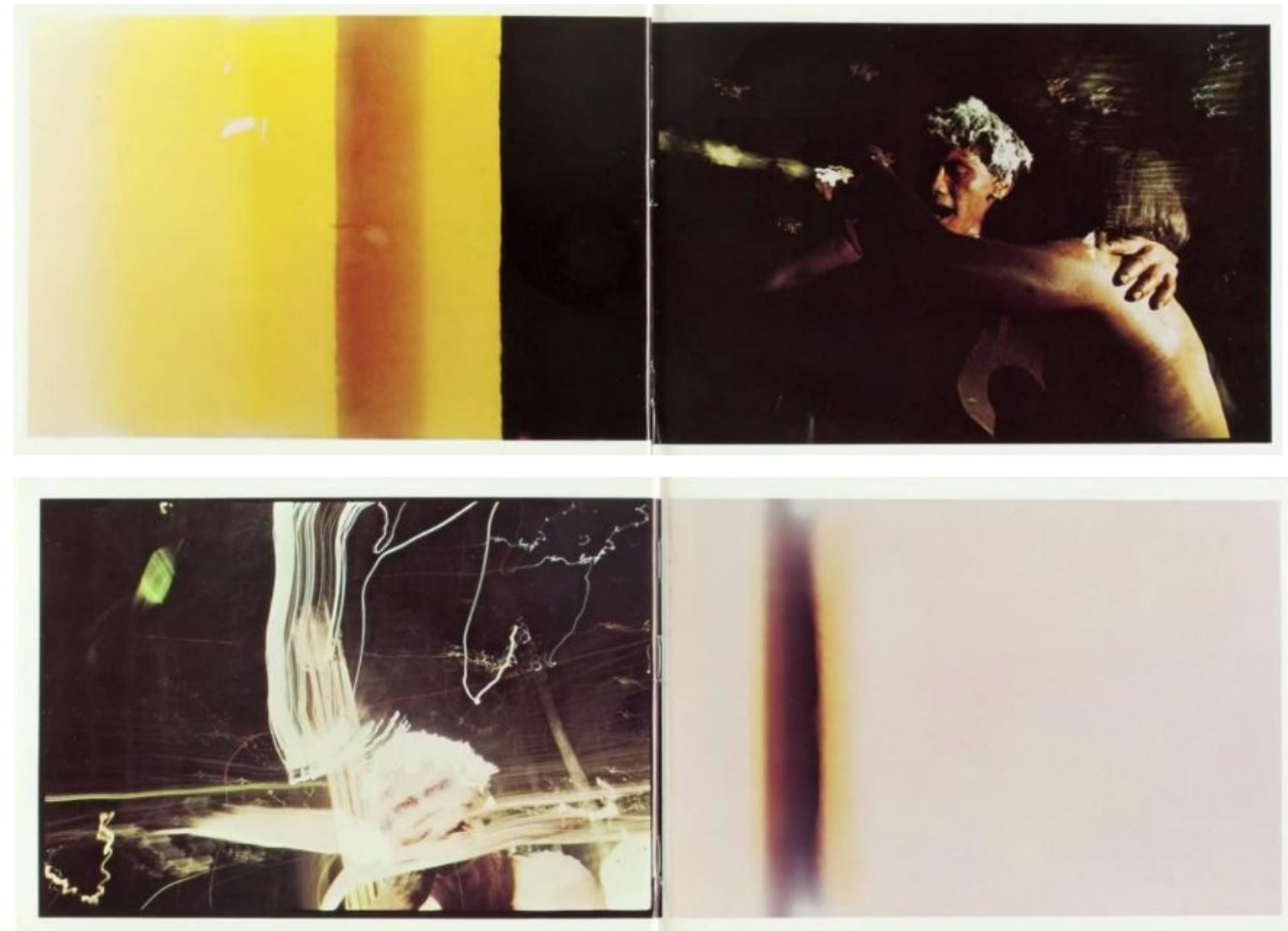

[Fonte: ANDUJAR, Claudia; LOVE, George. Amazônia. São Paulo: Praxis, 1978] 

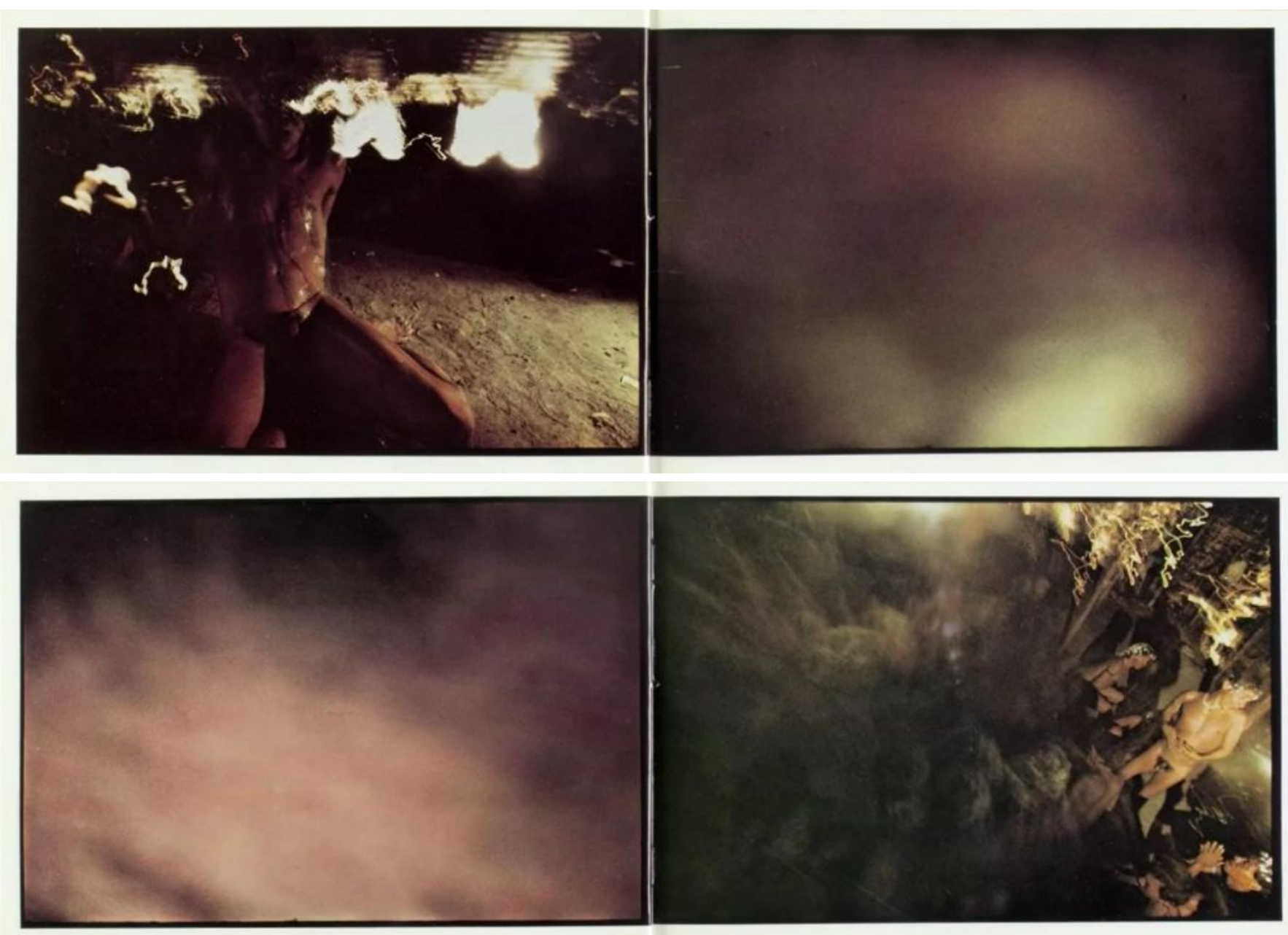

Fig. 6 - Páginas duplas de Amazônia.

[Fonte: ANDUJAR, Claudia; LOVE, George. Amazônia. São Paulo: Praxis, 1978]

Numa delas, um rapaz sentado sobre os joelhos, com o corpo molhado de suor e saliva é rodeado por manchas de luz branca amarelada, evocando a aproximação do xapiri. A página ao lado, coberta por manchas difusas de luz, parece aludir à sensação de vertigem após a inalação da yãkoana. Em outra dupla de páginas, algumas pessoas, em escala pequena, são vistas em diagonal próximas Revista Poiésis, Niterói, v. 23, n. 39, p. 224-252, jan./jun. 2022. [DOl: https://doi.org/10.22409/poiesis.v23i39.49154] 
à margem direita. Acima delas, impõem-se frenéticos caminhos de luz amarela. Esse pequeno conjunto ocupa menos de um terço da página, enquanto o restante é ocupado por massas amorfas de luz, resultantes do desfoque total dos motivos. Na página à esquerda, as manchas são ainda mais difusas, carecendo de qualquer referência a dados da realidade externa.
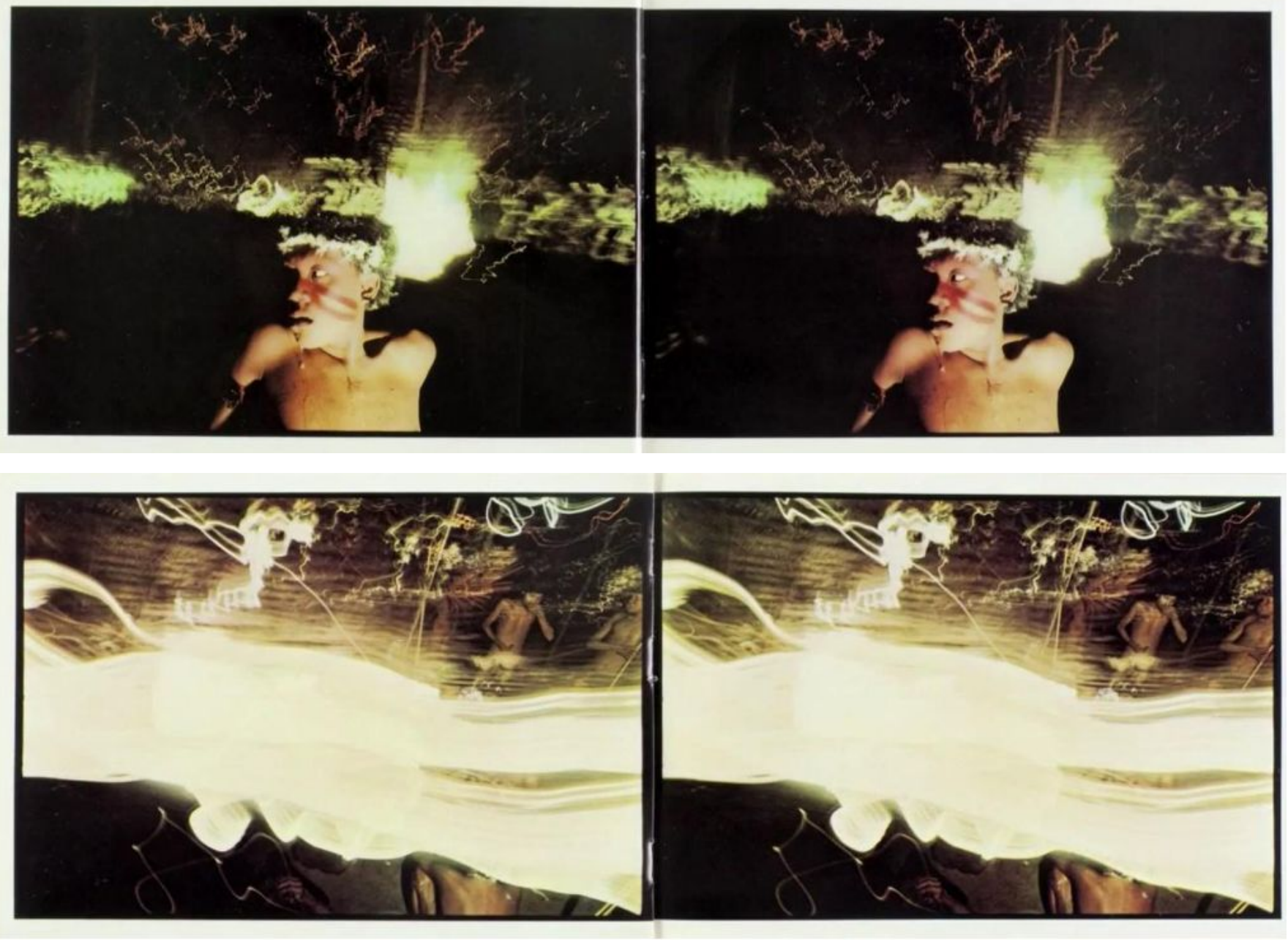

Fig. 7- Páginas duplas de Amazônia.

[Fonte: ANDUJAR, Claudia; LOVE, George. Amazônia. São Paulo: Praxis, 1978]

DE MORAES, Ana Carolina Albuquerque. Xamanismo em fotolivros de Claudia Andujar: Yanomami e Amazônia. 
Das páginas duplas que contêm imagens figurativas em ambos os lados, algumas apresentam fotografias identicamente duplicadas, o que pode aludir à visão multiplicada dos xamãs durante o transe [Fig.7]. Numa delas, um rapaz retratado do tórax para cima volta a cabeça e o olhar para um lado. Do nariz e da boca, escorrem muco e saliva, reação que comumente se segue à inalação da yãkoana. Por trás da cabeça, distribuem-se os frenéticos caminhos ondulantes de luz, sobretudo ao longo de uma linha horizontalizada. Em outra dupla de páginas, tais caminhos avolumam-se a tal ponto que se transformam em massa muito espessa de luz branca, que, em primeiro plano, corta horizontalmente a imagem, deixando atrás de si minúsculos elementos humanos. Os corpos, proporcionalmente pequenos, parecem aludir à submissão do homem à onipresença desse mundo sobre-humano, que pulsa por trás das a parências a reger e organizar a vida humana.

Em duas páginas duplas já mostradas [Figs. 6 e 7, embaixo], a posição da fotógrafa, que capta a cena de cima, parece sugerir uma troca de ponto de vista, na acepção do perspectivismo ameríndio de Viveiros de Castro [1996] e Tânia Stolze Lima [1996]. Segundo essa teoria, para os ameríndios, uma ampla gama de seres no universo é dotada de humanidade e agência: o que é ou não humano depende do ponto de vista de quem está na posição de sujeito. No passado absoluto, descrito pela mitologia, todos os seres eram humanos, cultural e morfologicamente, e a possibilidade de metamorfose entre eles era virtualmente infinita. Com o passar dos tempos, alguns perderam a forma humana, transformando-se em animais, vegetais, etc., preservando, porém, o espírito humano. A perda da unidade primordial e a diferenciação das espécies deu origem às múltiplas perspectivas. Embora o espírito humano permaneça transespecífico, cada corpo carrega consigo uma perspectiva única, um ponto de vista singular, irredutivelmente inscrito naquele corpo e apenas possível a partir dele. Oxamã, enquanto diplomata cósmico, consegue transitar entre as perspectivas, assumindo diferentes pontos de vista sem deixar de retornar ao seu próprio. Diferentes pontos de vista não significam diferentes representações sobre o mundo, mas sim, necessariamente, diferentes mundos: cada mundo só existe na perspectiva de quem está na posição de sujeito, não havendo a "coisa em si". O perspectivismo ameríndio é, assim, amplamente relacional, e as relações predador-presa constituem campo altamente propício para as inversões perspectivas. Por exemplo, "os animais predadores e os espíritos [...] veem os humanos como animais de presa, ao passo que os animais de presa veem os humanos como espíri- 
tos ou como animais predadores" [VIVEIROS DE CASTRO, 2002, p. 350]. Os espíritos, em particular, jamais viram presa: seu ponto de vista é sempre dominante. "[...] o que define os espíritos é, entre outras coisas, o fato de serem supremamente incomestíveis; isso os transforma em comedores por excelência, ou seja, em antropófagos" [VIVEIROS DE CASTRO, 2002, p. 392-393].

Nas imagens em questão, a fotógrafa parece assumir o ponto de vista privilegiado dos espíritos: de cima e de longe, visualiza os seres humanos como minúsculas criaturas, sem ser vista de volta por eles. Aliás, como reiteradamente afirmam Kopenawa e Albert [2015], os xapiri, em sua visão onipotente, veem sempre os humanos, mas apenas os xamãs são capazes de vê-los em contrapartida-e sob muitas condições. São os xapirique decidem para quais xamãs tornar-se-ão visiveis - aqueles que houverem cumprido todas as suas exigências de hábitos alimentares e comportamentais. A fotógrafa-xapiri parece, então, assumir momentaneamente a perspectiva daquele que pode ver sem ser visto, devorar sem ser devorado, detendo sempre o ponto de vista dominante.

Às vezes, a migração da consciência e o acesso a visões de outra natureza são associados a níveis de desconstrução da própria imagem fotográfica, ressaltando sua materialidade e criando laços de aparência com a pintura informalista. Numa sequência, um homem posiciona logo abaixo do nariz o utensílio pelo qual se sopra e inala yãkoana [Fig.8]. Andujar realiza intervenções de luz que se superpõem à parte de cima da cabeça do modelo, chegando até a cobri-la como um todo, como que a sugerir o acesso a outro patamar da consciência. As manchas de luz, ora brancas, ora rosadas, muito espessas e com alto grau de opacidade, chegam a lembrar manchas de tinta numa pintura abstracionista, aproximando - em termos de resultado, não de processo - a fotografia de Andujar da visualidade pictórica.

O ápice dessa relação parece surgir na sequência em que uma urna funerária na floresta, fotografada com filtro infravermelho de um ponto de vista rebaixado, transforma-se, na dupla seguinte de páginas, em manchas e riscos vermelhos e amarelos sobre fundo em que a referência à floresta é apenas uma evocação distante [Fig.9]. Os vermelhos que, na fotografia de origem, lembram sangue, fogo e morte parecem, nas páginas seguintes, levar esses significados ao paroxismo e, contraditoriamente, esvaziá-los na materialidade da imagem. 

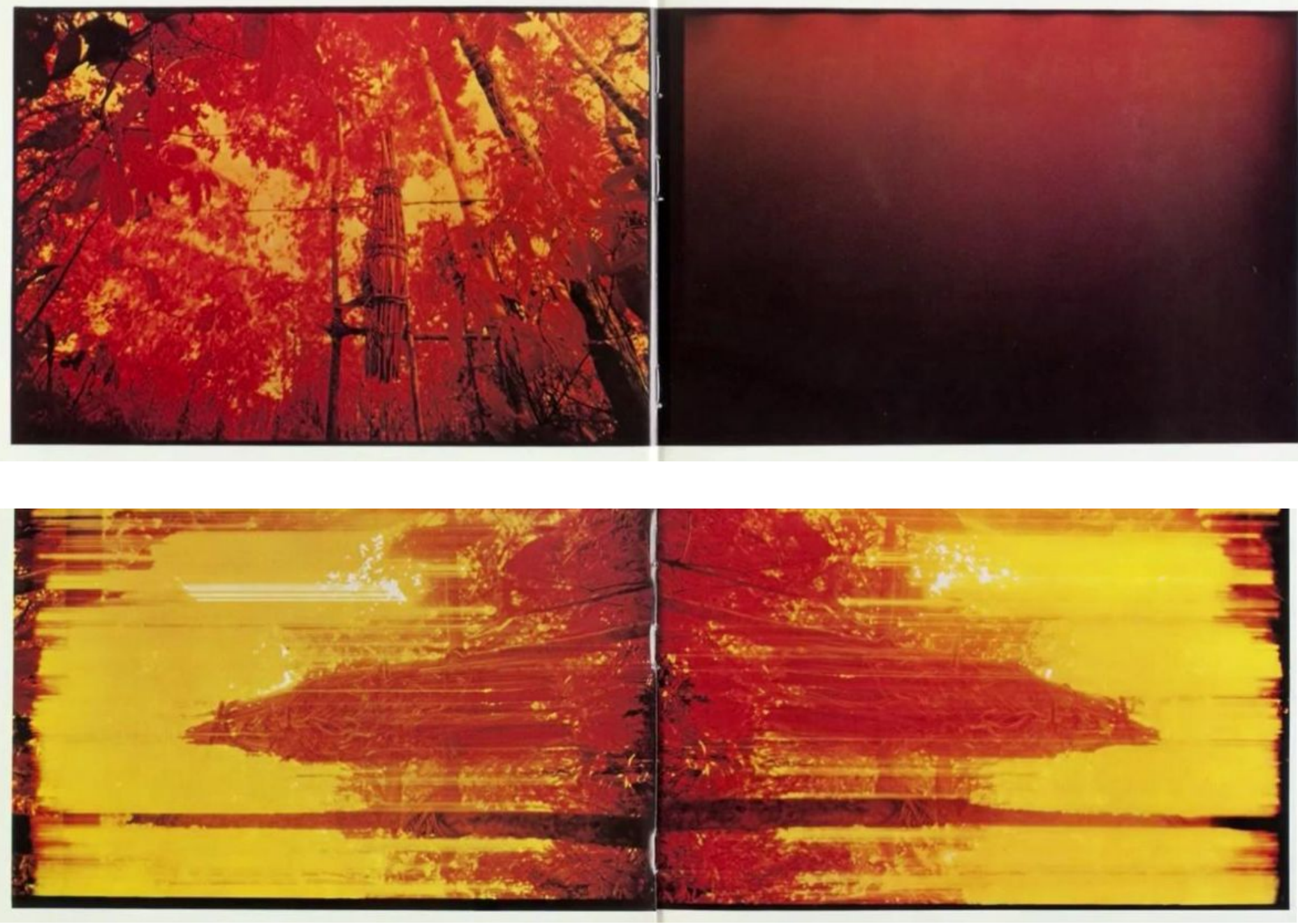

Fig. 9 - Páginas duplas de Amazônia.

[Fonte: ANDUJAR, Claudia; LOVE, George. Amazônia. São Paulo: Praxis, 1978]

DE MORAES, Ana Carolina Albuquerque. Xamanismo em fotolivros de Claudia Andujar: Yanomami e Amazônia. 


\section{CONSIDERAÇÕES FINAIS}

Yanomami, preto-e-branco, é sóbrio, sutil, objetivo. Sua poesia reside justamente na simplicidade plástica e projetual, na singeleza dos motivos, na visualidade franca e sugestiva. A fotógrafa encontra-se sempre na altura do retratado, dialogando de perto com seus modelos. Os enquadramentos fechados e a luz que acaricia delicadamente os corpos revelam apenas partes: o discurso é metonímico. O que vemos são fragmentos de corpos emergindo da escuridão: a negritude do fundo não nos permite a contextualização do espaço. Predominam os suaves contrastes claro-escuro, a luz viscosa que avoluma e, sutilmente, revela. Uma única imagem traz o brilho ofuscante dos xapiri, e os contrastes explodem para dar conta do assunto.

Já Amazônia, em cores, é exuberante, tátil, imprevisível. Sua poética é a do deslumbramento, da surpresa. "O que é isso?", perguntamo-nos inicialmente, apenas para nos darmos conta de que o "isso" não importa tanto; mais decisivas são as diversas sensações que nos transmitem as imagens, a tal "atmosfera" a que Love aludiu. Muito mais que registros de uma realidade exterior, as fotografias se pretendem construções de realidades possíveis. Assim como em Yanomami, o projeto gráfico é marcado pela simplicidade; a diferença fica por conta da natureza e das dimensões das imagens: a página dupla vista como um todo, sem margens internas, chega a lembrar a vastidão da tela de cinema. As posições dos fotógrafos são múltiplas: ora as vistas aéreas de Love, ora a relação horizontal de Andujar com os modelos, ora a vista de baixo que amplifica urna funerária e floresta. Em contraponto à visualidade franca de Yanomami, há aqui uma poética de recursos visuais múltiplos, de modo a evidenciar, continuamente, o pensamento técnico e construtivo da imagem fotográfica.

Enquanto Yanomamiapenas de leve toca no tema do xamanismo, Amazônia aborda-o fartamente, tanto em relação à quantidade e às dimensões das imagens como quanto à variedade de efeitos visuais utilizados. Em vários momentos, a câmera parece transformar-se em pincel, desenhando e pintando com a luz: a reprodutibilidade técnica sugerindo a gestualidade orgânica da mancha e do traço, a fotografia em diálogo com a introspecção de um Rothko, a catarse de um Pollock. Ora se evoca o deslocamento dos xapiri, ora a migração da consciência no transe xamânico, ora outros significados nunca esgotáveis. Esse desenhar e pintar com a câmera só é possível por meio de intensa experimentação técnica e exímio conhecimento das possibilida- 
des da fotografia analógica. Como sugeriu Love, era preciso conhecer bem as duas realidades: a amazônica e a fotográfica. No caso de Claudia, o conhecimento da realidade amazônica focava-se decisivamente na compreensão cultural dos Yanomami. O experimentalismo técnico buscava dar forma a seus conhecimentos etnológicos.
NOTAS

1 Além dos já citados artigos de minha autoria, frutos da pesquisa de doutorado em andamento, artigos recentes de outros autores também tecem relações entre obras de Andujar e o xamanismo yanomami [DUARTE, 2003; CASTANHEIRA, 2016; HATA, 2018; ANDRADE NETO, 2018; GARCEZ, 2020; CABRAL; MEDEIROS, 2020].

2 A pesquisa está sendo desenvolvida junto ao Programa de Pós-Graduação em Artes Visuais da Universidade Estadual de Campinas, sob orientação da Profa. Dra. Maria de Fátima Morethy Couto. Sou grata à Profa. Dra. Ilana Seltzer Goldstein, do Programa de Pós-Graduação em História da Arte da Universidade Federal de São Paulo, pelas valiosas contribuições, referentes ao campo da Antropologia, durante meu exame de qualificação. Agradeço também à Galeria Vermelho, nas pessoas de Jan Fjeld e Marcos Gallon, pelas entrevistas concedidas e os documentos disponibilizados.

3 A substância a que os Yanomami denominam yãkoana origina-se da pulverização da resina obtida, por exsudação, de tiras da casca da árvore Virola elongata [yãkoana hi]. Os xamãs - e demais membros da comunidade do sexo masculino - inalam o pó de yãkoana por meio de um tubo de madeira [horoma], posicionando a narina numa extremidade, enquanto o pó é soprado com força por alguém situado na outra [ALBERT; MILLIKEN, 2009].

4 Entre o povo Yanomami, o xamanismo é praticado pela quase totalidade dos homens de uma aldeia, sendo considerado uma etapa importante na formação de um homem adulto [TAYLOR, 1996; RAMALHO, 2008]. Apesar disso, o prestígio daqueles identificados pelo grupo como "xamãs" advém do fato de apenas eles serem considerados capazes de solucionar 
as querelas mais difíceis. $\bigcirc$ xamã yanomami passou necessariamente por uma iniciação dolorosa, repleta de esforço e privações, e dedicou/dedica muito mais tempo da sua vida à aprendizagem de cantos xamânicos, à inalação da substância psicoativa e ao contato com espíritos auxiliares durante o transe induzido por essa substância. Quanto mais experiente o xamã, maior a quantidade e a variedade de espíritos que atendem aos seus chamados, espíritos dos quais ele pode lançar mão durante as sessões xamânicas, a fim de solucionar os mais diversos obstáculos na comunidade [KOPENAWA; ALBERT, 2015].

5 Em 1978, Andujar lançou, além dos dois livros analisados neste artigo, a obra que levava a público os resultados da pesquisa da FAPESP: Mitopoemas Yãnomam, publicada pela Olivetti do Brasil S.A., em edição trilíngue [português-italiano-inglês], com introdução de Pietro Maria Bardi [ANDUJAR, 1978b]. 6 Termo que, para os Yanomami, designa entidades, normalmente invisíveis, que se encontram por toda parte, observando e regulando a vida terrena. Cada ser florestal possui um respectivo xapiri, que the corresponde no mundo invisível. Todos os xapiri apresentam morfologia humanoide, aludindo a um passado primordial em que todos os seres eram humanos, não havendo diferenciação entre espécies [KOPENAWA; ALBERT, 2015].

$7 \bigcirc$ termo "desaculturação" é aqui utilizado como sinônimo de "aculturação". Segundo a teoria antropológica da aculturação, o contato prolongado entre culturas distintas torna-as cada vez mais semelhantes, numa interinfluência mútua que pode levar à fusão entre elas [GOW, 2015, p.35-37]. O antropólogo Darcy Ribeiro, parceiro de Andujar, preferia falar em "transfiguração étnica": "um processo natural, cultural [...] através do qual um povo permanece ele mesmo à medida que muda e se adapta às condições de sobrevivência. Trata-se de um processo de autoconservação em que eles vão conservando o que é possível de sua cultura, mas não se fecham" [RIBEIRO, apud GRUPIONI; GRUPIONI, 1997, p. 191]. 
ALBERT, Bruce; MILLIKEN, William. Urihi a: a terra-floresta Yanomami. São Paulo: Instituto Socioambiental [ISA]; Institut de Recherche pour le Developpement [IRD], 2009. Disponivel em https://acervo. socioambiental.org/acervo/publicacoes-isa/urihi-terra-floresta-yanomami. Acesso em 20 nov. 2020.

ANDRADE NETO, Alberto Luiz de. Brilho e sonhos: caminhando com Andujar, Kopenawa e Albert. REIA, ano 5, v. 5, n. 1, p.5-27, 2018. Disponível em https://periodicos.ufpe.br/revistas/reia/article/ view/236427. Acesso em 15 jun. 2021.

ANDUJAR, Claudia. Depoimento sobre a série Sonhos Yanomami. [2005?]. Documento digital contendo 1 página. Acervo Galeria Vermelho.

ANDUJAR, Claudia. Entrevista a Rubens Fernandes Jr., durante o 2. Fórum Latino-americano de Fotografia de São Paulo, ocorrido no Itaú Cultural. São Paulo, 24 de outubro de 2010, n.p. Disponível em http://docplayer.com.br/10422408-2-forum-latino-americano-de-fotografia-de-sao- paulo-rubens-fernandes-jr-entrevista-claudia-andujar.html. Acesso em 22 out. 2019.

ANDUJAR, Claudia. Mitopoemas Yãnomam. São Paulo: Olivetti do Brasil S.A., 1978b.

ANDUJAR, Claudia. Poesia, pintura e fotografia. Entrevista a Augusto Massi, Eduardo Brandão e Álvaro Machado. In: ANDUJAR, Claudia. A vulnerabilidade do ser. São Paulo: Cosac Naify; Pinacoteca do Estado, 2005, p.102-125. 
ANDUJAR, Claudia. Yanomami: frente ao eterno. Uma vivência entre os índios Yãnomam. São Paulo: Práxis, 1978a.

ANDUJAR, Claudia. LOVE, George. Amazônia. São Paulo: Praxis, 1978.

CABRAL, Sabrina Alvernaz Silva; MEDEIROS, Sérgio Luiz Rodrigues. Andujar e a captura do corpo. Remate de Males, Campinas-SP, v. 40, n. 1, p.147-164, jan./jun. 2020. Disponível em https://periodicos.sbu.unicamp.br/ojs/index.php/remate/article/view/8657704.

Acesso em 20 jun. 2021.

CASTANHEIRA, Rafael. Poéticas de resistência: a representação do Outro nas fotografias de Claudia Andujar e Miguel Rio Branco. Mosaico, Goiânia, v. 9, n. 1, p.125-144, jan./jun. 2016. Disponível em http://seer.pucgoias.edu.br/index.php/mosaico/article/view/4757. Acesso em 17 jun. 2021.

Claudia Andujar: O invisivele Reahu/ The invisible and Reahu [1974-1976]. Documento digital contendo 21 páginas. Acervo Galeria Vermelho.

DUARTE, Rogério. Olhares do infinito - notas sobre a obra de Claudia Andujar. Studium, Campinas, n. 12, p.40-61, 2003. Disponivel em https://econtents.bc.unicamp.br/inpec/index.php/studium/article/view/11747. Acesso em 15 jun. 2021.

GARCEZ, João Pedro. A autora como xamã ou o que deve a arte de Andujar aos Yanomami?. Wamon, Manaus, v. 5, n. 2, p.159-171, 2020. Disponível em https://www.periodicos.ufam.edu.br/index. php/wamon/article/view/8231. Acesso em 20 jun. 2021.

GOW, Peter. Steps towards an ethnographic theory of acculturation. Etnografia. Praktyki, Teorie, Doświadczenia, Gdańsk, v. 1, p.34-39, 2015. Disponível em https://www.ejournals.eu/Etnografia/2015/1-2015/art/8981/. Acesso em 23 ago. 2020. 
GRUPIONI, Luís Donisete Benzi; GRUPIONI, Maria Denise Fajardo. Entrevista com Darcy Ribeiro. Horizontes Antropológicos, Porto Alegre, ano 3, n. 7, p.158-200, nov. 1997. Disponível em https://www. scielo.br/scielo.php?script=sci_arttext\&pid=S0104-71831997000300158\&lng=pt\&tlng=pt. Acesso em 25 ago. 2020.

HATA, Luli. Sonhos xamânicos na arte contemporânea. Artefactum, Rio de Janeiro, ano X, v. 16, n. 1, n.p., 2018. Disponível em http://artefactum.rafrom.com.br/index.php/artefactum/article/ view/1612. Acesso em: 19 jun. 2021.

KOPENAWA, Davi; ALBERT, Bruce. A queda do céu: palavras de um xamã yanomami. Tradução de Beatriz Perrone-Moisés. São Paulo: Companhia das Letras, 2015.

LIMA, Tânia Stolze. O dois e seu múltiplo: reflexões sobre o perspectivismo em uma cosmologia tupi. Mana, Rio de Janeiro, v. 2, n. 2, p.21-47, out. 1996. Disponível em http://www.scielo.br/pdf/ mana/v2n2/v2n2a02.pdf. Acesso em 9 mar. 2021.

MORAES, Ana Carolina Albuquerque de. Claudia Andujar e Marcello Tassara: o transe yanomami na fotografia e no cinema. Artelogie, Paris, n. 12, p.1-17, 2018. Disponível em https://journals.openedition.org/artelogie/2572?lang=pt. Acesso em: 10 jun. 2021.

MORAES, Ana Carolina Albuquerque de. Do converso ao Xamã: Religiosidade Yanomami em Claudia Andujar. In: FREIRE, Luiz; QUIRICO, Tamara; VALLE, Arthur; ANDRADE, Marco Pasqualini de [Orgs.]. Anais do XXXVIII Colóquio do Comitê Brasileiro de História da Arte: Arte e Erotismo - prazer e transgressão na história da arte. Florianópolis: Comitê Brasileiro de História da Arte - CBHA, 2019 [2018], p.233-244. Disponível em http://www.cbha.art.br/coloquios/2018/anais/pdfs/02\%20 Ana\%20Carolina\%20Albuquerque.pdf. Acesso em 10 jun. 2021. 
MORAES, Ana Carolina Albuquerque de. Sonhos xamânicos: diálogos entre Claudia Andujar e Davi Kopenawa. In: BULHÕES, Maria Amélia; FETTER, Bruna; ROSA, Nei Vargas da [Orgs.]. Arte além da arte: Anais do $2^{\circ}$ Simpósio Internacional de Relações Sistêmicas da Arte [recurso eletrônico]. Porto Alegre: Universidade Federal do Rio Grande do Sul, 2020, p.131-140. Disponível em https://2simposioirsablog.wordpress.com. Acesso em 10 jun. 2021.

NOGUEIRA, Thyago. Claudia Andujar: a luta yanomami. In: NOGUEIRA, Thyago [Org.]. Claudia Andujar: a luta yanomami. São Paulo: IMS, 2018, p.161-248.

RAMALHO, Moisés. Os Yanomami e a morte. 2008.163 p. Tese [Doutorado em Antropologia Social]. Faculdade de Filosofia, Letra e Ciências Humanas, Universidade de São Paulo. São Paulo.

TAYLOR, Kenneth I. A Geografia dos Espíritos: o xamanismo entre os Yanomami setentrionais. In: LANGDON, E. Jean Matteson [Org.]. Xamanismo no Brasil: novas perspectivas. Florianópolis: Editora da UFSC, 1996, p. 117-151.

VIVEIROS DE CASTRO, Eduardo. A floresta de cristal: notas sobre a ontologia dos espíritos amazônicos. Cadernos de campo, São Paulo, n. 14/15, p.319-338, 2006. Disponível em http://www.revistas.usp.br/cadernosdecampo/article/view/50120/55708. Acesso em 4 jul. 2018.

VIVEIROS DE CASTRO, Eduardo. A inconstância da alma selvagem e outros ensaios de antropologia. São Paulo: Cosac Naify, 2002.

VIVEIROS DE CASTRO, Eduardo. Os pronomes cosmológicos e o perspectivismo ameríndio. Mana, Rio de Janeiro, v. 2, n. 2, p.115-144, out. 1996. Disponível em http://www.scielo.br/pdf/mana/v2n2/ v2n2a05.pdf. Acesso em 9 mar. 2021. 